Check for updates

Cite this: RSC Adv., 2017, 7, 30941

\title{
Degradation of azo dye with activated peroxygens: when zero-valent iron meets chloride $\uparrow$
}

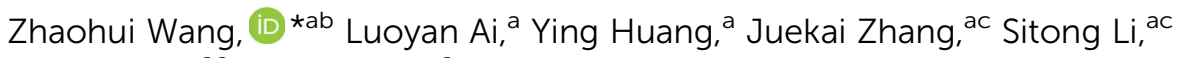 \\ Jiawei Chen ${ }^{\text {ac }}$ and Fei Yang ${ }^{a}$
}

Degradation of acid orange 7 (AO7) by $\mathrm{Fe}^{0}$-based Advance Oxidation Process (AOPs) with common peroxygens, persulfate (PS), peroxymonosulfate (PMS) and hydrogen peroxide $\left(\mathrm{H}_{2} \mathrm{O}_{2}\right)$, was investigated, in which sulfate radicals $\left(\mathrm{SO}_{4}{ }^{-}\right)$) and/or hydroxyl radicals $\left({ }^{\circ} \mathrm{OH}\right)$ are powerful oxidizing species. The effects of $\mathrm{Fe}^{\mathrm{O}}$ dosage, peroxygen concentration, initial $\mathrm{pH}$ and the presence of chloride on the degradation of $\mathrm{AO} 7$ were examined. The $\mathrm{AO} 7$ degradation efficiencies by four systems, including $\mathrm{Fe}^{0}$, $\mathrm{Fe}^{0} / \mathrm{H}_{2} \mathrm{O}_{2}, \mathrm{Fe}^{0} / \mathrm{PMS}$ and $\mathrm{Fe} / \mathrm{PS}$ were compared. AO7 degradation rate by $\mathrm{Fe}^{0}$ activated $A O P s$ in descending order is $\mathrm{H}_{2} \mathrm{O}_{2} \geqq P S>P M S$. Increasing acidity and iron dosage favored a rapid degradation of AO7. The presence of chloride greatly inhibited dye removal in $\mathrm{Fe}^{0} / \mathrm{H}_{2} \mathrm{O}_{2}$ and $\mathrm{Fe} / \mathrm{PS}$ systems, whilst accelerated dye degradation was observed in the $\mathrm{Fe}^{0} / \mathrm{PMS}$ system. In contrast, mineralization of $\mathrm{AO} 7$ in the $\mathrm{Fe} / \mathrm{PMS} / \mathrm{Cl}^{-}$system was minimal, because of formation of lots of refractory chlorinated phenols as identified by GC-MS. These findings are useful for selecting the most appropriate technology for textile wastewater treatment, depending on the wastewater constituents and $\mathrm{pH}$.

Received 5th April 2017

Accepted 9th June 2017

DOI: $10.1039 / \mathrm{c} 7 \mathrm{ra03872k}$

rsc.li/rsc-advances reported oxidation of ZVI with oxygen can lead to the formation of reactive oxygen species (ROS) capable of degrading pollutants that cannot be reduced by ZVI. Yields of ROS from oxygen activation with ZVI are significantly affected by $\mathrm{pH} .^{12,13} \mathrm{Fe}^{0}$ or ferrous ions (Fe(II)) released from $\mathrm{Fe}^{0}$ corrosion, react with oxygen to produce $\mathrm{H}_{2} \mathrm{O}_{2}$, which further reacts with $\mathrm{Fe}(\mathrm{II})$ via a well-known Fenton reaction to produce ${ }^{\circ} \mathrm{OH}$ (eqn (1)-(4)). ${ }^{\mathbf{1 4 - 1 6}}$

$$
\begin{gathered}
\mathrm{Fe}^{0}+1 / 2 \mathrm{O}_{2}+\mathrm{H}_{2} \mathrm{O} \rightarrow \mathrm{Fe}^{2+}+2 \mathrm{OH}^{-} \\
\mathrm{Fe}^{0}+\mathrm{O}_{2}+2 \mathrm{H}^{+} \rightarrow \mathrm{Fe}^{2+}+\mathrm{H}_{2} \mathrm{O}_{2} \\
\mathrm{Fe}^{0}+\mathrm{H}_{2} \mathrm{O}_{2} \rightarrow \mathrm{Fe}^{2+}+2 \mathrm{OH}^{-} \\
\mathrm{Fe}^{2+}+\mathrm{H}_{2} \mathrm{O}_{2} \rightarrow \mathrm{Fe}^{3+}+\mathrm{OH}^{-}+\cdot \mathrm{OH}
\end{gathered}
$$

In addition to oxygen, ZVI has been successfully used to activate a series of peroxygens like $\mathrm{H}_{2} \mathrm{O}_{2}$, persulfate (PS, $\mathrm{S}_{2} \mathrm{O}_{8}{ }^{2-}$ ) and peroxymonosulfate (PMS, $\left.\mathrm{HSO}_{5}{ }^{-}\right) \cdot{ }^{17-21} \mathrm{Fe}^{0}$ is a strong electron donor $\left(E^{0}\left(\mathrm{Fe}^{2+} / \mathrm{Fe}^{0}\right)=-0.447 \mathrm{~V} v s \text {. NHE }\right)^{19}$ and is expected to induce reductive decomposition of $\mathrm{H}_{2} \mathrm{O}_{2}\left(E^{0}\left(\mathrm{H}_{2} \mathrm{O}_{2} / \mathrm{H}_{2} \mathrm{O}\right)=\right.$ $1.77 \mathrm{~V} v s$. NHE $),{ }^{22} \mathrm{PS}\left(E^{0}\left(\mathrm{~S}_{2} \mathrm{O}_{8}{ }^{2-} / \mathrm{SO}_{4}{ }^{2-}\right)=2.01 \mathrm{~V} v s\right.$. NHE) and $\mathrm{PMS}\left(E^{0}\left(\mathrm{HSO}_{5}{ }^{-} / \mathrm{HSO}_{4}{ }^{-}\right)=1.85 \mathrm{~V} v s \text {. NHE}\right)^{23}$ (eqn (5) and (6)). ZVI is thought to act as a continuous slow-release source of $\mathrm{Fe}$ (II) during peroxygens activation. The peroxo bond in these peroxygens breaks down by $\mathrm{Fe}(\mathrm{II})$ to form highly reactive oxidants, such as ${ }^{\circ} \mathrm{OH}$ and $\mathrm{SO}_{4}{ }^{-}{ }^{-}$(eqn (7) and (8)). Therefore, peroxygens activation with ZVI has been applied to degrade several contaminants such as aniline, bisphenol, trichloroethene, phenol, acid black 24 and pentachlorophenol. ${ }^{17,24-28}$ To the best

\footnotetext{
${ }^{a}$ State Environmental Protection Engineering Center for Pollution Treatment and Control in Textile Industry, College of Environmental Science and Engineering, Donghua University, Shanghai, 201620, China. E-mail: zhaohuiwang@dhu.edu.cn ${ }^{b}$ International Center for Balanced Land Use (ICBLU), The University of Newcastle, Callaghan, NSW 2308, Australia

'Shanghai Shixi High School (SSHS), Jing'an District, Shanghai, 200040, China $\dagger$ Electronic supplementary information (ESI) available: The online version of this article contains supplementary material, which is available to authorized users. See DOI: $10.1039 / \mathrm{c} 7 \mathrm{ra0} 3872 \mathrm{k}$
} 
of our knowledge, a comparative study on the degradation of the same azo dye by ZVI-based peroxygens activation has not been reported.

$$
\begin{gathered}
\mathrm{Fe}^{0}+\mathrm{S}_{2} \mathrm{O}_{8}^{2-} \rightarrow \mathrm{Fe}^{2+}+2 \mathrm{SO}_{4}{ }^{2-} \\
\mathrm{Fe}^{0}+\mathrm{HSO}_{5}{ }^{-} \rightarrow \mathrm{Fe}^{2+}+\mathrm{SO}_{4}^{2-}+\mathrm{OH}^{-} \\
\mathrm{Fe}^{2+}+\mathrm{S}_{2} \mathrm{O}_{8}{ }^{2-} \rightarrow \mathrm{Fe}^{3+}+\mathrm{SO}_{4}^{2-}+\mathrm{SO}_{4}{ }^{--} \\
\mathrm{Fe}^{2+}+\mathrm{HSO}_{5}{ }^{-} \rightarrow \mathrm{Fe}^{3+}+\mathrm{OH}^{-}+\mathrm{SO}_{4}{ }^{--}
\end{gathered}
$$

The present study was an attempt to compare the degradation efficiencies of Acid Orange 7 (AO7, a typical azo dye) by ZVI activation with three common peroxygens. The effects of $\mathrm{pH}$, ZVI dosage, chloride ions on dye degradation were investigated. Additionally, TOC and GC-MS measurement were conducted to characterize the extent of mineralization and intermediate products during treatment.

\section{Experimental}

\subsection{Materials}

All chemical reagents used in this study were in AR grade and were used without further purification. Hydrogen peroxide $(30 \%, \mathrm{v} / \mathrm{v})$, sodium chloride $(\mathrm{NaCl})$, sodium hydroxide $(\mathrm{NaOH})$, sulfuric acid $\left(\mathrm{H}_{2} \mathrm{SO}_{4}, 98 \%\right)$, and the $\mathrm{Fe}^{0}$ powder were obtained from Sinopharm. Acid orange $7\left(\mathrm{C}_{16} \mathrm{H}_{11} \mathrm{~N}_{2} \mathrm{O}_{4} \mathrm{SNa}\right)$ and Oxone® $\left(2 \mathrm{KHSO}_{5} \cdot \mathrm{KHSO}_{4} \cdot \mathrm{K}_{2} \mathrm{SO}_{4}\right)$ were bought from Sigma-Aldrich. Potassium persulfate $\left(\mathrm{K}_{2} \mathrm{~S}_{2} \mathrm{O}_{8}\right)$ was purchased from Alfa Aesar. All solutions were prepared with deionized water.

\subsection{Experimental procedures}

The degradation experiments were conducted at room temperature in $250 \mathrm{~mL}$ batch reactors, and used the same batch reactors to make all comparisons. For all the experiments, the initial concentration of $\mathrm{AO} 7$ was $0.08 \mathrm{mmol} \mathrm{L}^{-1}$. The initial $\mathrm{pH}$ values of all solutions were adjusted by $0.1 \mathrm{~mol} \mathrm{~L}^{-1}$ sulfuric acid or $0.1 \mathrm{~mol} \mathrm{~L}^{-1}$ sodium hydroxide. At given intervals, the solution was sampled and examined on U-2910 spectrophotometer at $484 \mathrm{~nm}$ for testing the degradation kinetics. For the measurement of mineralization and products, samples were quenched by sodium nitrite with a ratio of $\mathrm{NaNO}_{2} /$ react solution was $1: 1$. All experiments were conducted in duplicate.

\subsection{Analysis}

The analysis of the degradation intermediates was carried out by gas chromatography-mass spectrometry (Agilent 7890A model GC with DB-5 MS. $30 \mathrm{~mm} \times 320 \mu \mathrm{m} \times 0.5 \mu \mathrm{m}$ capillary column coupled with 5975A inert XL MSD model MS). Helium was used as the carrier gas at a rate of $1.0 \mathrm{~mL} \min ^{-1} .1 \mu \mathrm{L}$ samples were injected at $250{ }^{\circ} \mathrm{C}$ in splitless mode. The sequence of GC temperature program was followed as: start at $40{ }^{\circ} \mathrm{C}$, hold for $2 \mathrm{~min} ; 40-100{ }^{\circ} \mathrm{C}\left(12{ }^{\circ} \mathrm{C} \mathrm{min}\right) ; 100-200{ }^{\circ} \mathrm{C}\left(5{ }^{\circ} \mathrm{C} \mathrm{min}\right) ; 200-$ $270{ }^{\circ} \mathrm{C}\left(20^{\circ} \mathrm{C} \min ^{-1}\right)$, hold for $5 \mathrm{~min}$. The ion source temperature was maintained at $230{ }^{\circ} \mathrm{C}$. Qualitative detector was used in the electron impact (EI) mode at $70 \mathrm{eV}$ with the mass scanned range $(30-400 \mathrm{~m} / \mathrm{z})$. The unknown peaks were identified using NIST08 mass spectral library database.

The mineralization of $\mathrm{AO} 7$ aqueous solutions was examined by a Shimazu TOC- $\mathrm{V}_{\mathrm{CPH}}$ analyzer. The sample volumes were 10 $\mathrm{mL}$. The flow rate and pressure of carrying gas (air) was set as

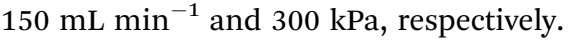

A pseudo first-order kinetic model is used to describe the degradation kinetics in different activation systems. The kinetic expression is represented as eqn (9), where $C_{t}$ is the residual AO7 concentration at time $t(\mathrm{~min}) ; C_{0}$ is the initial $\mathrm{AO} 7$ concentration. $k$ denotes the observed pseudo first-order rate

Table 1 The calculated pseudo first-order rate constant $\left(10^{-3} \mathrm{~min}^{-1}\right)$ of $\mathrm{AO} 7$ oxidation in $\mathrm{Fe}^{0}$-peroxygens systems

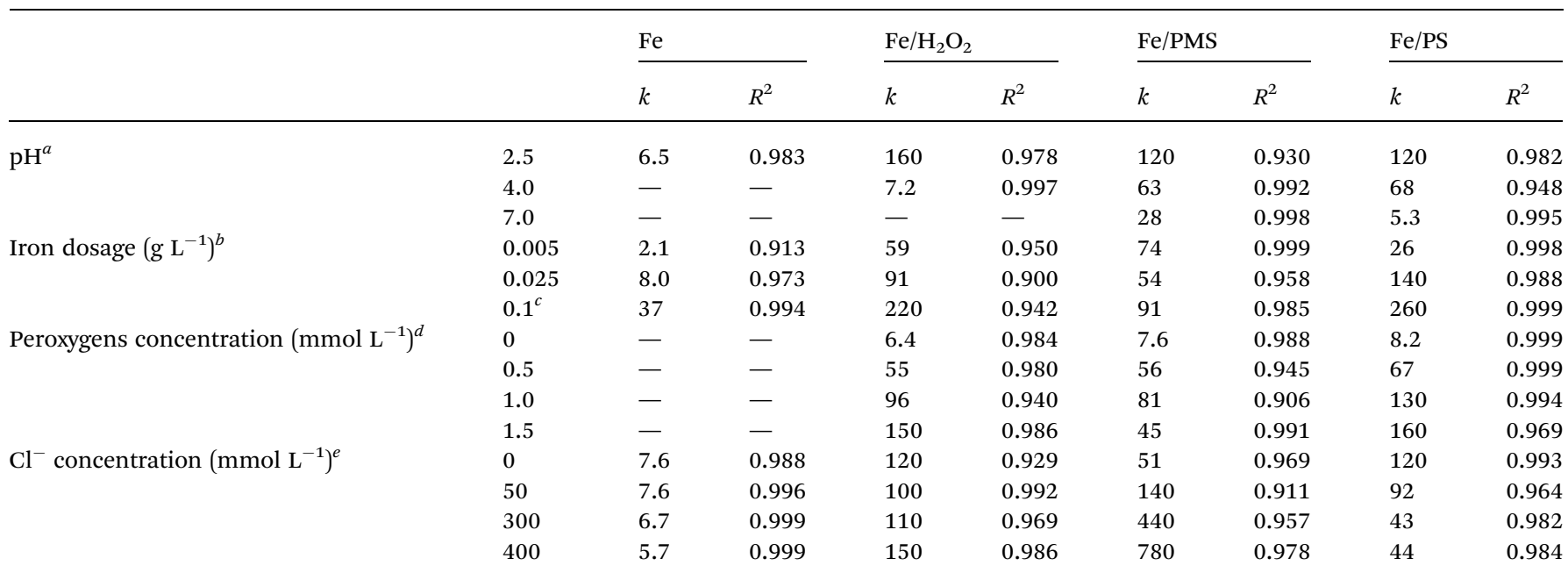

${ }^{a}$ Conditions: $m\left(\mathrm{Fe}^{0}\right)=0.025 \mathrm{~g} \mathrm{~L}^{-1}, c(\mathrm{Ox})=1.0 \mathrm{mmol} \mathrm{L}^{-1}, c(\mathrm{AO} 7)=0.08 \mathrm{mmol} \mathrm{L}^{-1} .^{b}$ Conditions: $c(\mathrm{Ox})=1.0 \mathrm{mmol} \mathrm{L}^{-1}, c(\mathrm{AO} 7)=0.08 \mathrm{mmol} \mathrm{L}{ }^{-1}, \mathrm{pH}^{-1}$ $=2.5{ }^{c}$ Conditions: in Fe/PMS, the maximum dosage of $\mathrm{Fe}^{0}$ was $0.05 \mathrm{~g} \mathrm{~L}^{-1} \cdot{ }^{d}$ Conditions: $m\left(\mathrm{Fe}^{0}\right)=0.025 \mathrm{~g} \mathrm{~L}^{-1}, c(\mathrm{AO})=0.08 \mathrm{mmol} \mathrm{L}{ }^{-1}, \mathrm{pH}^{-1}=2.5$.

${ }^{e}$ Conditions: $m\left(\mathrm{Fe}^{0}\right)=0.025 \mathrm{~g} \mathrm{~L}^{-1}, c(\mathrm{AO} 7)=0.08 \mathrm{mmol} \mathrm{L}^{-1}, c(\mathrm{Ox})=1.0 \mathrm{mmol} \mathrm{L}^{-1}, \mathrm{pH}=2.5$. 
constant $\left(\mathrm{min}^{-1}\right)$. The constant $k$ is calculated by the slope of a plot of $\ln \left(C_{t} / C_{0}\right)$ versus $t$ and is summarized in Table 1.

$$
C_{t} / C_{0}=\mathrm{e}^{-k t}
$$

\section{Results and discussion}

\subsection{Effectiveness of the various activated peroxygens}

Experiments were conducted to determine effectiveness of $\mathrm{Fe}^{0}$ activated peroxygens on the removal of $\mathrm{AO} 7$ by changing initial $\mathrm{pH}$ of solution while keeping $\mathrm{Fe}^{0}$ loading and peroxygens concentration constant. As shown in Fig. 1, degradation efficiency of $\mathrm{AO} 7$ decreased with the increasing $\mathrm{pH}$ value. About $20 \%$ of dye was decomposed in $\mathrm{Fe}^{0} /$ air system at $\mathrm{pH}=2.5$, while no measurable degradation was observed at other tested $\mathrm{pH}$. Under acidic conditions, indirect oxidation of dye by strong oxidants generated by $\mathrm{Fe}^{0}$ (eqn (4), (7) and (8)) was responsible for $\mathrm{AO} 7$ degradation besides the direct reductive decolorization on iron surface which results in the cleavage of the azo bonds of AO7 (eqn (10)). ${ }^{\mathbf{1 3}}$

$$
-\mathrm{N}=\mathrm{N}-+2 \mathrm{H}^{+}+2 \mathrm{e}^{-} \rightarrow-\mathrm{NH}+\mathrm{HN}_{-}
$$

Mielczarski et al. ${ }^{29}$ reported that iron oxide/hydroxide on the $\mathrm{Fe}^{0}$ surface was thin at $\mathrm{pH}=3.0$, but mainly existed in the solution. Accumulation of iron oxide on the iron surface significantly affected the electron transfer between $\mathrm{Fe}^{0}$ and oxygen (or dye) at $\mathrm{pH}>4.0,{ }^{29}$ thus inhibiting the dye degradation. Among the three tested $\mathrm{Fe}^{0}$-peroxygens systems, $\mathrm{Fe}^{0} / \mathrm{H}_{2} \mathrm{O}_{2}$ system exhibited a better degradation efficiency at $\mathrm{pH}=2.5$, with a constant rate of $0.16 \mathrm{~min}^{-1}$, higher than those $(0.12$ $\min ^{-1}$ ) in two $\mathrm{SO}_{4}{ }^{-}$-based systems (Table 1 ). This can be ascribed to the higher oxidation capacity of ${ }^{\circ} \mathrm{OH}$ than $\mathrm{SO}_{4}{ }^{--}$at highly acidic $\mathrm{pH}$. However, at higher $\mathrm{pH}$ (4.0 and 7.0), $\mathrm{Fe}^{0} / \mathrm{H}_{2} \mathrm{O}_{2}$ system became inefficient towards dye degradation. At $\mathrm{pH}$ 7.0, no measurable degradation of dye occurred. In contrast, despite of reduction in reaction rates at $\mathrm{pH} 4.0$ and $7.0, \mathrm{Fe}^{0} / \mathrm{PMS}$ and $\mathrm{Fe}^{0} / \mathrm{PS}$ systems still led to a considerable degradation of AO7. Some researchers tried to explain it from the perspective of electron transfer mechanism. ${ }^{18}$ They thought electron transfer from the iron surface to $\mathrm{H}_{2} \mathrm{O}_{2}$ undergoes an inner-sphere electron transfer process that is slower than outer-sphere electron transfer mechanism as supposed in $\mathrm{Fe}^{0} / \mathrm{PMS}$ and $\mathrm{Fe}^{0} / \mathrm{PS}$ systems. This proposed explanation is supported by Al-Shamsi et $a .^{18}$ and Rastogi et $a l^{30}$ who both observed that activated $\mathrm{H}_{2} \mathrm{O}_{2}$ system was less efficient to oxidize trichloroethylene (TCE) and polychlorinated biphenyls (PCBs) compared to the activated PS and PMS systems.

\subsection{Effect of $\mathrm{Fe}^{\mathrm{O}}$ dosage}

Effects of $\mathrm{Fe}^{0}$ dosage $\left(0.005,0.025,0.1 \mathrm{~g} \mathrm{~L}^{-1}\right)$ on dye degradation by four $\mathrm{Fe}^{0}$-based systems were investigated. As seen in Fig. 2, without $\mathrm{Fe}^{0}$, peroxygen itself can not directly oxidize dye within the examined time. Degradation efficiency of four tested systems all increased with increasing iron dosage. For example, about $90 \%$ of dye was degraded in $\mathrm{Fe}^{0} / \mathrm{H}_{2} \mathrm{O}_{2}$ process at $10 \mathrm{~min}$, while other reactions with relatively lower $\mathrm{Fe}^{0}$ dosage $(0.005$, $0.025 \mathrm{~g} \mathrm{~L}^{-1}$ ) needed longer reaction time of 20 and $30 \mathrm{~min}$ to achieve the comparable removal of dye, respectively. Increasing $\mathrm{Fe}^{0}$ dosage from 0.005 to $0.1 \mathrm{~g} \mathrm{~L}^{-1}$ led to a $17.6,3.7$ and 10 -fold increase in pseudo first-order rate constant in $\mathrm{Fe}^{0}, \mathrm{Fe}^{0} / \mathrm{H}_{2} \mathrm{O}_{2}$ and

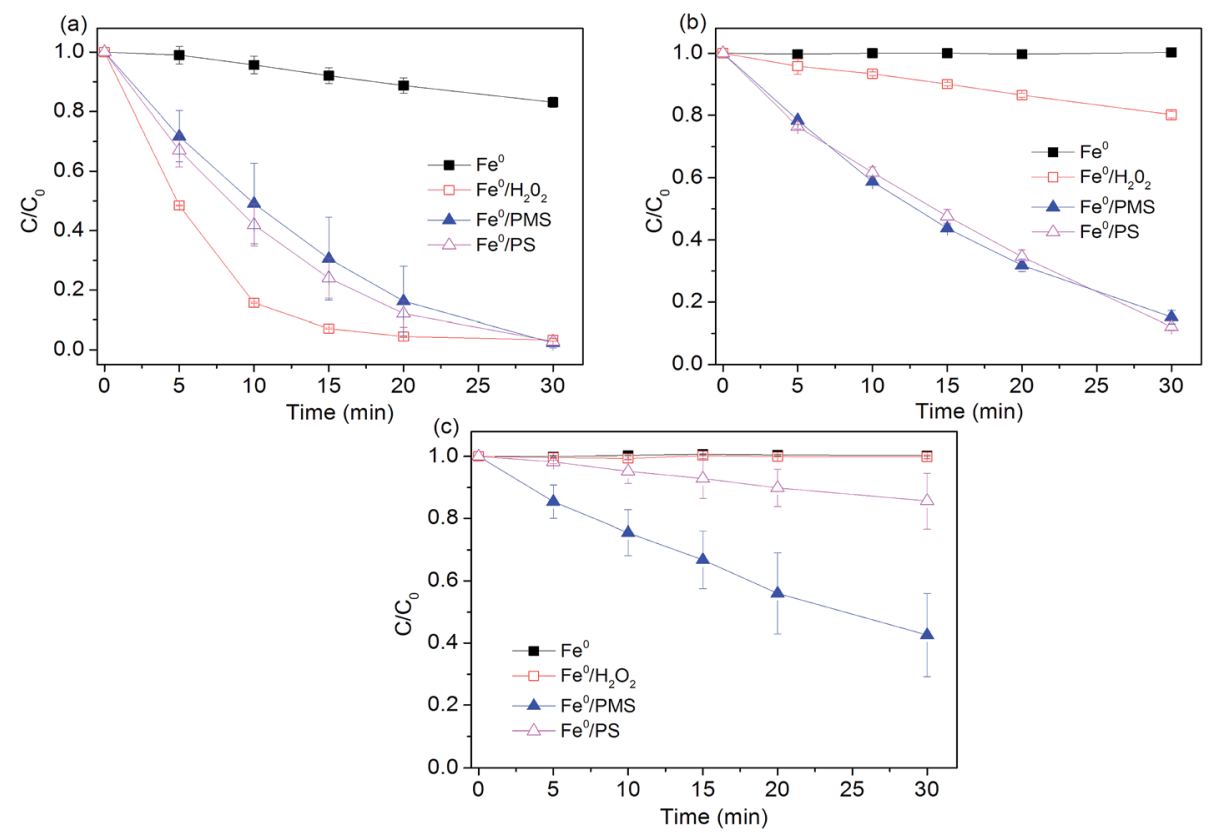

Fig. 1 Effect of $\mathrm{pH}$ value on $\mathrm{AO} 7$ degradation rates. (a) $\mathrm{pH}_{0}=2.5$; (b) $\mathrm{pH}_{0}=4.0$; (c) $\mathrm{pH}_{0}=7.0$. Conditions: $c(\mathrm{AO})_{0}=0.08 \mathrm{mmol} \mathrm{L}^{-1} ; m(\mathrm{Fe})_{0}=$ $0.025 \mathrm{~g} \mathrm{~L}^{-1} ; c(\mathrm{Ox})_{0}=1 \mathrm{mmol} \mathrm{L}^{-1}$. 
$\mathrm{Fe}^{0} / \mathrm{PS}$, respectively. Increase in total surface area and availability of more $\mathrm{Fe}^{0}$ reactive sites should be responsible for the enhanced degradation of dye with increasing iron dosage.

\subsection{Effects of peroxygens doses}

The influence of peroxygens concentrations on the oxidation of AO7 with PS, PMS, $\mathrm{H}_{2} \mathrm{O}_{2}$ was studied at the ZVI dosage of
0.005 g. As expected, Fig. 3 shows that degradation rates of AO7 increased as PS and $\mathrm{H}_{2} \mathrm{O}_{2}$ dosage increased because of the enhanced generation of hydroxyl radical and sulfate radical as availability of their precursors (i.e. PS and $\mathrm{H}_{2} \mathrm{O}_{2}$ ) was increased. Briefly, the rate constant for dye degradation increased by a factor of 2.7 and 2.4 as concentration of $\mathrm{H}_{2} \mathrm{O}_{2}$ and PS increased from 0.5 to $1.5 \mathrm{mmol} \mathrm{L}^{-1}$. As shown in Fig. $3 \mathrm{~b}$, the extent of AO7 degradation increased from $20 \%$ to $92.1 \%$ when
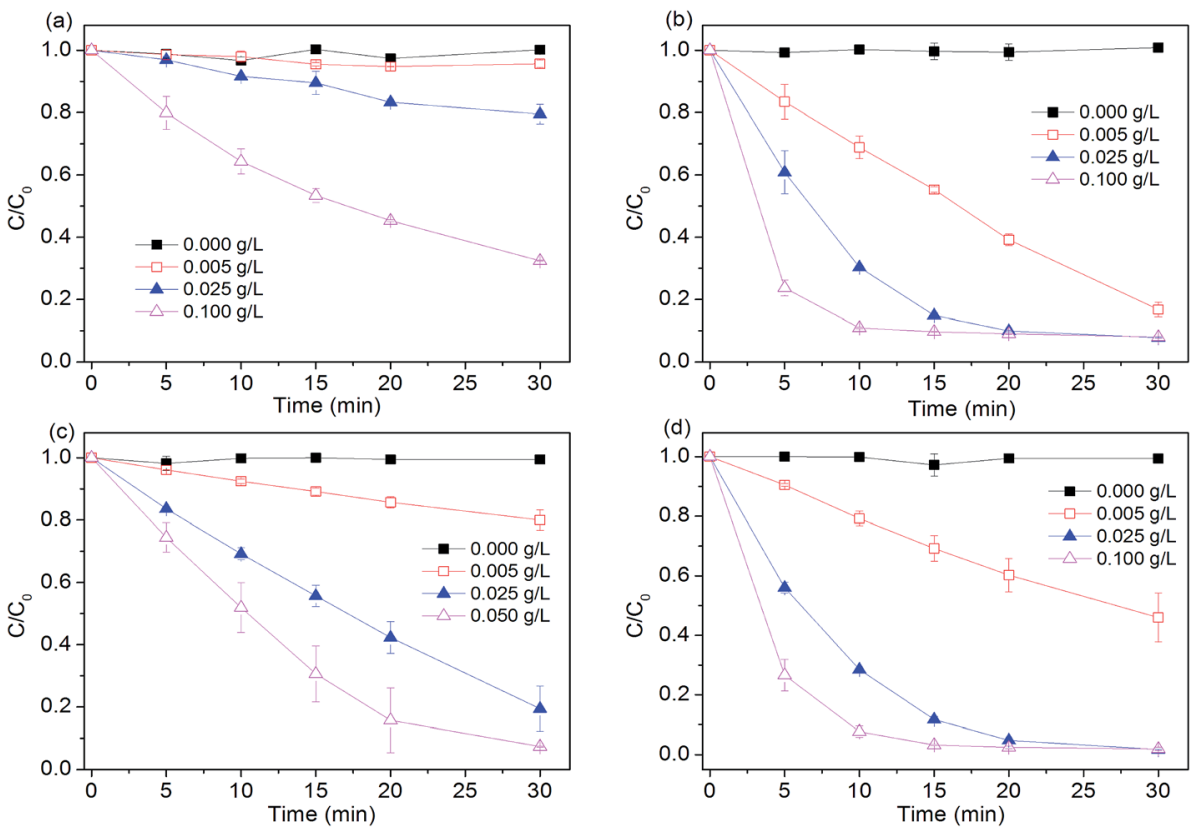

Fig. 2 Effect of $\mathrm{Fe}^{0}$ dosage on $\mathrm{AO} 7$ removal in four systems. (a) $\mathrm{Fe}^{0}$; (b) $\mathrm{Fe}^{0} / \mathrm{H}_{2} \mathrm{O}_{2}$; (c) $\mathrm{Fe}^{0} / \mathrm{PMS}$; (d) $\mathrm{Fe}^{0} / \mathrm{PS}$. Conditions: $\mathrm{C}(\mathrm{AO} 7)_{0}=0.08 \mathrm{mmol} \mathrm{L}^{-1}$; $c(\mathrm{Ox})_{0}=1 \mathrm{mmol} \mathrm{L}^{-1} ; \mathrm{pH}_{0}=2.5 \pm 0.2$.
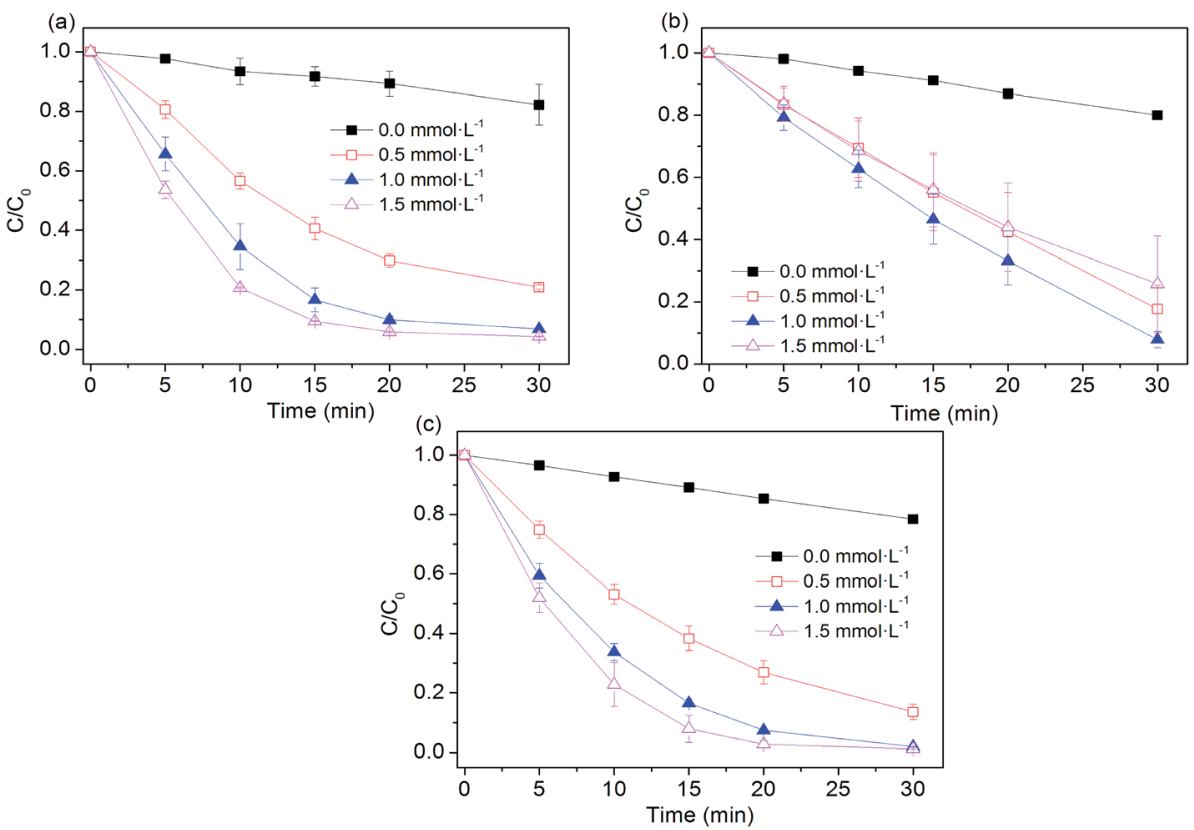

Fig. 3 Effect of peroxygens concentration on AO7 removal in four systems. (a) $\mathrm{Fe}^{0} / \mathrm{H}_{2} \mathrm{O}_{2}$; (b) $\mathrm{Fe}^{0} / \mathrm{PMS}$; (c) $\mathrm{Fe} / \mathrm{PS}$. Conditions: $\mathrm{c}\left(\mathrm{AO}\right.$ ) ( $_{0}=$ $0.08 \mathrm{mmol} \mathrm{L}^{-1} ; m\left(\mathrm{Fe}^{0}\right)_{0}=0.025 \mathrm{~g} \mathrm{~L}^{-1} ; \mathrm{pH}_{0}=2.5 \pm 0.2$. 
PMS concentration increased from 0 to $1 \mathrm{mmol} \mathrm{L}^{-1}$ within 30 min. As PMS concentration was over $1 \mathrm{mmol} \mathrm{L}^{-1}$, the removal of $\mathrm{AO} 7$ was decreased to about $70 \%$. A similar trend was also observed during the oxidative degradation of bisphenol A (BPA) by UV activated PMS. ${ }^{31}$ An excess of $\mathrm{HSO}_{5}{ }^{-}$may scavenge parts of $\mathrm{SO}_{4}{ }^{-}$radicals and generate the less reactive $\mathrm{SO}_{5}{ }^{-}$ radicals (eqn (11)), ${ }^{31,32}$ thus decreasing the degradation efficiency of dye pollutant.

$$
\mathrm{HSO}_{5}^{-}+\mathrm{SO}_{4}^{\cdot-} \rightarrow \mathrm{HSO}_{4}^{-}+\mathrm{SO}_{5}^{\cdot-}
$$

\subsection{Effect of $\mathrm{Cl}^{-}$concentration}

Higher level of $\mathrm{NaCl}$ is one of the remarkable feature of textile wastewater, as large amount of $\mathrm{NaCl}\left(50-80 \mathrm{~g} \mathrm{~L}^{-1}\right)$ is frequently applied in dyeing processes in order to improve dye fixation and completion. $^{33}$ Our previous studies demonstrated that performance of $\mathrm{SO}_{4}{ }^{-}$-based advanced oxidation processes (SR-AOPs) is significantly affected by the presence of chloride. ${ }^{34-43}$ Therefore, it is necessary to examine efficiencies of four $\mathrm{Fe}^{0}$-based processes in the presence of chloride. As shown in Fig. 4, the $\mathrm{NaCl}$ in aqueous solution did not obviously affect the dye removal in the $\mathrm{Fe}^{0}$ system. Effects of chloride on $\mathrm{Fe}^{0}$-induced pollutant removal are quite complicated, depending on the nature of pollutants to be treated. For example, the presence of chloride can destroy the passive oxide layers and help to maintain efficiency of $\mathrm{Fe}^{0}$ for nitrobenzene reduction. ${ }^{44}$ However, Hwang et $a l .{ }^{45}$ reported that a higher concentration of $\mathrm{NaCl}\left(>3 \mathrm{~g} \mathrm{~L}^{-1}\right)$ had a significant inhibitory effect on nitrate reduction by $\mathrm{Fe}^{0}$, although $\mathrm{Fe}^{0}$ is known as a pitting and crevice corrosion promoter. ${ }^{46}$

In the $\mathrm{Fe}^{0} / \mathrm{H}_{2} \mathrm{O}_{2}$ and $\mathrm{Fe}^{0} / \mathrm{PS}$ systems, degradation rates of $\mathrm{AO} 7$ decreased in the presence of chloride. The negative effects of chloride ion on the efficiency of the $\mathrm{Fe}^{0} / \mathrm{H}_{2} \mathrm{O}_{2}$ and $\mathrm{Fe}^{0} / \mathrm{PS}$ systems may be explained by (Laat and Le 2006): ${ }^{47}$ (1) the formation of $\mathrm{Fe}(\mathrm{III})$ or $\mathrm{Fe}(\mathrm{II})$-chlorocomplexes $\left(\mathrm{FeCl}^{+}, \mathrm{FeCl}^{2+}\right.$, $\mathrm{FeCl}_{2}^{+}$) (eqn (12)-(14)) and (2) the scavenging effect of chloride ion for hydroxyl and sulfate radicals (eqn (15)-(18)). When chloride concentrations were less than $50 \mathrm{mmol} \mathrm{L}^{-1}$, degradation efficiency of TCE, ${ }^{48} p$-nitrosodimethylaniline ${ }^{49}$ and $\mathrm{AO} 7$ (ref. 50) by PS activation with $\mathrm{Fe}^{0}$ was not significantly affected. In the presence of excess chloride, the reaction of ${ }^{\circ} \mathrm{OH}$ or $\mathrm{SO}_{4}{ }^{\cdot-}$ with $\mathrm{Cl}^{-}$leads to the formation of chlorine atoms $\left(\mathrm{Cl}^{\circ}\right)\left(E^{0}\left(\mathrm{Cl}^{*}\right)\right.$ $\left.\mathrm{Cl}^{-}\right)=2.41 \mathrm{~V} v s$. NHE) and of dichloride anion radicals $\left(\mathrm{Cl}_{2}{ }^{-}\right)$ $\left(E^{0}\left(\mathrm{Cl}_{2}{ }^{\cdot-} / 2 \mathrm{Cl}^{-}\right)=2.09 \mathrm{~V}\right.$ vs. NHE $) .^{51} \mathrm{Cl}^{\cdot} / \mathrm{Cl}_{2}{ }^{\cdot-}$ can oxidize $\mathrm{H}_{2} \mathrm{O}_{2}$ and $\mathrm{Fe}$ (II) and but are less reactive with organic solutes than either ${ }^{\circ} \mathrm{OH}$ or $\mathrm{SO}_{4}{ }^{\cdot-}$. It should be noted that dye degradation was significantly accelerated in $\mathrm{Fe}^{0} / \mathrm{PMS} / \mathrm{Cl}^{-}$systems. For example, at $\left[\mathrm{Cl}^{-}\right]=400 \mathrm{mmol} \mathrm{L}{ }^{-1}, k$ increased 15 times higher than that in the absence of chloride. Our previous investigations found that PMS, rather than $\mathrm{H}_{2} \mathrm{O}_{2}$ and PS, could directly react with $\mathrm{Cl}^{-}$to produce $\mathrm{HOCl}$ and $\mathrm{Cl}_{2}$ (eqn (19) and (20)), ${ }^{37-43,51}$ enhancing the dye bleaching rate.

$$
\begin{gathered}
\mathrm{Fe}^{2+}+\mathrm{Cl}^{-} \leftrightarrow \mathrm{FeCl}^{+} \\
\mathrm{Fe}^{3+}+\mathrm{Cl}^{-} \leftrightarrow \mathrm{FeCl}^{2+} \\
\mathrm{Fe}^{3+}+2 \mathrm{Cl}^{-} \leftrightarrow \mathrm{FeCl}_{2}^{+} \\
\mathrm{Cl}^{-}+\cdot \mathrm{OH} \leftrightarrow \mathrm{ClOH}^{-} \\
\mathrm{ClOH}^{-}+\mathrm{H}^{+} \leftrightarrow \mathrm{H}_{2} \mathrm{O}+\mathrm{Cl}^{\cdot} \\
\mathrm{Cl}^{-}+\mathrm{SO}_{4}^{\cdot-} \leftrightarrow \mathrm{Cl}^{\cdot}+\mathrm{SO}_{4}^{2-}
\end{gathered}
$$
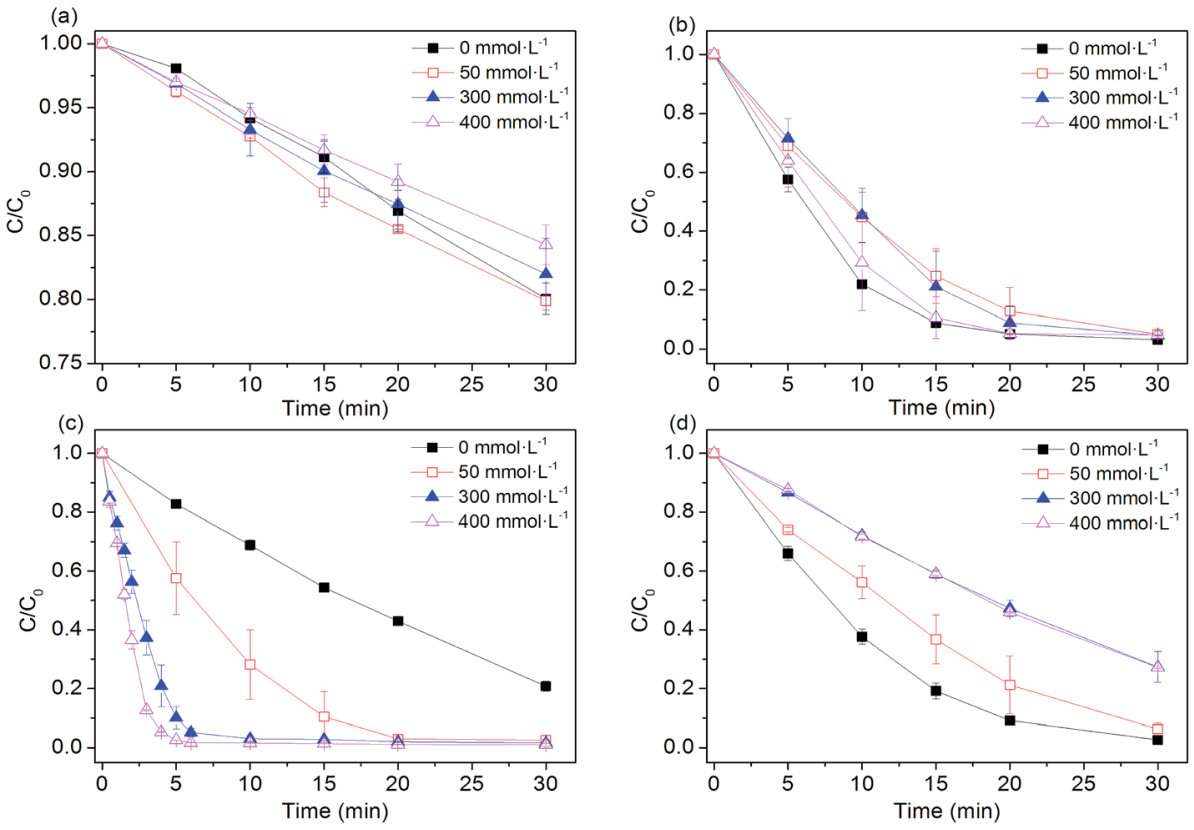

Fig. 4 Effect of chloride ions on $\mathrm{AO}$ degradation rates. (a) $\mathrm{Fe}^{0}$; (b) $\mathrm{Fe}^{0} / \mathrm{H}_{2} \mathrm{O}_{2}$; (c) $\mathrm{Fe}^{0} / \mathrm{PMS}$; (d) $\mathrm{Fe}^{0} / \mathrm{PS}$. Conditions: $c(\mathrm{AO})$ ) $_{0}=0.08$ mmol $\mathrm{L}^{-1}$; $m\left(\mathrm{Fe}^{0}\right)_{0}=0.025 \mathrm{~g} \mathrm{~L}^{-1} ; c(\mathrm{Ox})_{0}=1 \mathrm{mmol} \mathrm{L}{ }^{-1} ; \mathrm{pH}_{0}=2.5 \pm 0.2$. 


$$
\begin{gathered}
\mathrm{Cl}^{\cdot}+\mathrm{Cl}^{-} \leftrightarrow \mathrm{Cl}_{2}{ }^{--} \\
\mathrm{Cl}^{-}+\mathrm{HSO}_{5}{ }^{-} \rightarrow \mathrm{SO}_{4}{ }^{2-}+\mathrm{HOCl} \\
2 \mathrm{Cl}^{-}+\mathrm{HSO}_{5}{ }^{-}+\mathrm{H}^{+} \rightarrow \mathrm{SO}_{4}{ }^{2-}+\mathrm{Cl}_{2}+\mathrm{H}_{2} \mathrm{O}
\end{gathered}
$$

\section{5. $\mathrm{AO7}$ mineralization and byproducts identification}

As evidenced in the previous studies, chlorinated organic intermediates would be generated when amounts of chloride are present in SR-AOPs. Therefore, it is necessary to identify the reaction byproducts and evaluate the mineralization, besides testing degradation rates. GC-MS data (Fig. S1-S18, $\uparrow$ Table 2) show that some chlorinated compounds were produced in SRAOPs. Seven chlorinated phenols, including 2,3,6-trichlorophenol, 2,4,5-trichlorophenol, 2,4,6-trichlorophenol, 3,4dichlorophenol, 2,5-dichlorophenol, 2,3-dichlorophenol, 2,4dichlorophenol, were identified in $\mathrm{Fe}^{0} / \mathrm{PMS} / \mathrm{Cl}^{-}$system, whereas only three chlorophenols like 2,4,5-trichlorophenol, 2,4,6-trichlorophenol, 2,3,5-trichlorophenol were detected in $\mathrm{Fe}^{0} / \mathrm{PS} / \mathrm{Cl}^{-}$system. According to the known Material Safety Data Sheet (MSDS) of pure chemical, acute toxicity, expressed as rat
Lethal Dose, $50 \%$ (LD50), are $820 \mathrm{mg} \mathrm{kg}^{-1}$ for 2,4,5-trichlorophenol, $820 \mathrm{mg} \mathrm{kg}^{-1}$ for 2,4,6-trichlorophenol, $1685 \mathrm{mg}$ $\mathrm{kg}^{-1}$ for 3,4-dichlorophenol, $2376 \mathrm{mg} \mathrm{kg}^{-1}$ for 2,3-dichlorophenol and $47 \mathrm{mg} \mathrm{kg}^{-1}$ for 2,4-dichlorophenol, respectively, much greater than $3418 \mathrm{mg} \mathrm{kg}^{-1}$ for their parent compound, AO7. This indicates that AO7 was transformed to more toxic and recalcitrant organic byproducts although $\mathrm{AO} 7$ itself has been efficiently degraded in $\mathrm{Fe}^{0}$-based oxidation systems.

Fig. 5 illustrates that $15.1 \%$ of $\mathrm{AO} 7$ could be mineralized without the addition of chloride after 30 min oxidation in $\mathrm{Fe}^{0}$ / $\mathrm{H}_{2} \mathrm{O}_{2}$ system. The extent of mineralization in descending order is $\mathrm{Fe}^{0} / \mathrm{H}_{2} \mathrm{O}_{2}>\mathrm{Fe}^{0} / \mathrm{PS}>\mathrm{Fe}^{0} / \mathrm{PMS}>\mathrm{Fe}^{0}$ (Fig. 5a). In the presence of chloride, TOC removal were dramatically decreased in four systems (Fig. 5b). In particular, no measurable TOC removal were observed in $\mathrm{Fe}^{0} / \mathrm{PMS}$ system, in sharp contrast to its rapid degradation rate as shown in Fig. 4. In combination with the GC-MS data, it is evident that $\mathrm{AO} 7$ in $\mathrm{Fe}^{0} / \mathrm{PMS} / \mathrm{Cl}^{-}$system was only converted to some chlorinated byproducts, although it was rapidly bleached. In general, extents of mineralization in these tested systems were not satisfactory. It is probably because (1) AO7 is just degraded via a chromophore cleavage, as evidenced by GC-MS; (2) $\mathrm{Fe}^{0}$, as a strong reductant, may continuously

Table 2 The transformation products during oxidation of $\mathrm{AO} 7$ in $\mathrm{Fe}^{0}$-peroxygens systems

Systems

Identified by products

$\mathrm{Fe}^{0} / \mathrm{Cl}^{-}$

$\mathrm{Fe}^{0} / \mathrm{H}_{2} \mathrm{O}_{2} / \mathrm{Cl}^{-}$<smiles>C/C=C(\C)C(=O)O</smiles>

$\mathrm{Fe}^{0} / \mathrm{PS} / \mathrm{Cl}^{-}$<smiles>O=C(O)c1ccccc1</smiles><smiles>Oc1ccc2ccccc2c1</smiles><smiles>Oc1cc(Cl)c(Cl)cc1Cl</smiles><smiles>Oc1c(Cl)cc(Cl)cc1Cl</smiles><smiles>Oc1cc(Cl)cc(Cl)c1Cl</smiles><smiles>Nc1ccccc1</smiles><smiles>O=C(O)c1ccccc1</smiles><smiles>Oc1cc(Cl)ccc1Cl</smiles><smiles>Oc1cccc(Cl)c1Cl</smiles><smiles>Oc1ccc(Cl)c(Cl)c1</smiles>

$\mathrm{Fe}^{0} / \mathrm{PMS} / \mathrm{Cl}^{-}$<smiles>Oc1ccc(Cl)cc1Cl</smiles><smiles>Oc1cc(Cl)c(Cl)cc1Cl</smiles><smiles>Oc1c(Cl)ccc(Cl)c1Cl</smiles><smiles>Oc1c(Cl)cc(Cl)cc1Cl</smiles> 
(a)

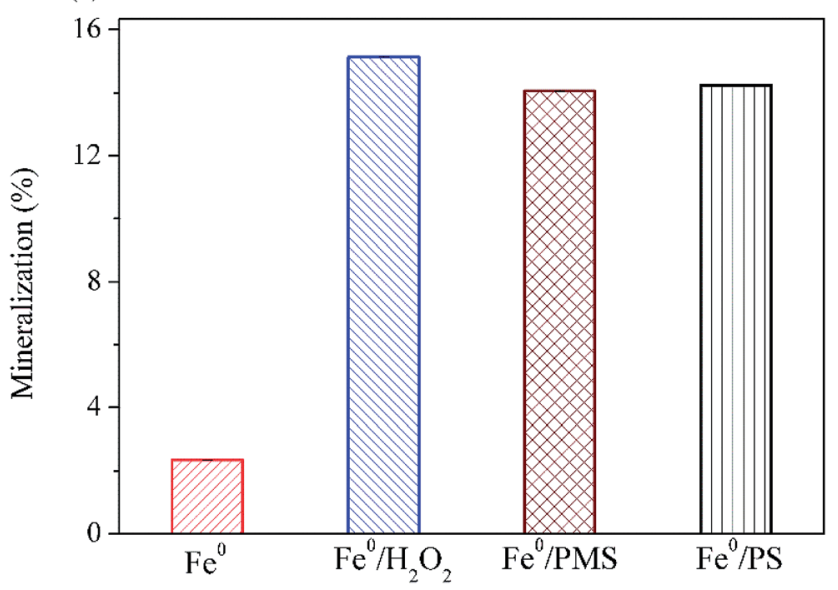

(b)

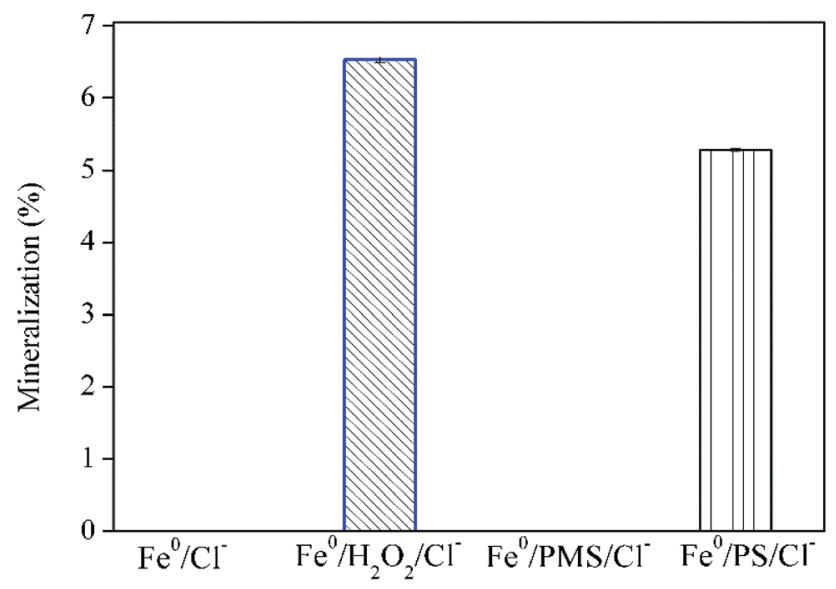

Fig. 5 Variation of mineralization of $\mathrm{AO} 7$ with different peroxygens after 30 min. (a) Without $\mathrm{Cl}^{-}$; (b) with $\mathrm{Cl}^{-}$. Conditions: $\mathrm{c}(\mathrm{AO} 7)_{0}=$ $0.08 \mathrm{mmol} \mathrm{L}^{-1} ; m\left(\mathrm{Fe}^{0}\right)_{0}=0.025 \mathrm{~g} \mathrm{~L}^{-1} ; c(\mathrm{Ox})_{0}=1 \mathrm{mmol} \mathrm{L}^{-1} ; \mathrm{pH}_{0}=2.5$ $\pm 0.2 ; \mathrm{c}(\mathrm{NaCl})_{0}=50 \mathrm{mmol} \mathrm{L}^{-1}$ (if any).

consume highly reactive species which are critical for a complete mineralization of organic pollutant. The development of processes combining Fe-based peroxygens oxidation systems with further biological methods is a possible route to improve the removal of recalcitrant degradation intermediates.

\subsection{Mechanism discussion}

Under the present experimental conditions, two major mechanisms govern the removal process of dye: (1) reduction and (2) degradation. $\mathrm{Fe}^{0}$ undergoes a couples of corrosion reactions in acidic solution, accompanying with reduction of $\mathrm{O}_{2}$ or pollutants on its surface. Azo dye reduction is thought to involve a two-step process. ${ }^{52}$ Initially, nascent hydrogen is generated after the oxidation of $\mathrm{Fe}^{0}$. The newly formed $\mathrm{Fe}^{2+}$ on the $\mathrm{Fe}^{0}$ surface enables the azo group of AO7 catalytically hydrogenated to form short-lived hydrazo intermediates, followed by a further hydrogenation of the unstable transition products to form stable aromatic amines.

In addition to dye pollutant, $\mathrm{O}_{2}$ can be directly reduced by $\mathrm{Fe}^{0}$ powder to generate $\mathrm{H}_{2} \mathrm{O}_{2}$ (eqn (2)), providing the reactants for the Fenton reaction yielding ${ }^{\circ} \mathrm{OH}$ radical. A faster iron redox cycle at the iron surface takes place through a rapid reduction of $\mathrm{Fe}^{3+}$ to $\mathrm{Fe}^{2+}$ by $\mathrm{Fe}^{0}$. The kinetic rates of iron corrosion are dependent upon the intrinsic reactivity of the selected $\mathrm{Fe}$ material and other environmental factors, such redox conditions and $\mathrm{pH} .{ }^{53}$ At neutral $\mathrm{pH}$, a thick layer of iron oxides, maghemite or lepidocrocite, is formed as a result of hydrolysis, precipitation and transformation of $\mathrm{Fe}^{3+}$, thereby diminishing the reactivity of $\mathrm{Fe}^{0}$.

In the presence of peroxygens, ${ }^{\circ} \mathrm{OH}$ or $\mathrm{SO}_{4}{ }^{-}$is produced from the catalytic decomposition of $\mathrm{H}_{2} \mathrm{O}_{2}$, PS and PMS by $\mathrm{Fe}^{0}$ and/or $\mathrm{Fe}^{2+}$. Surface-catalyzed $\mathrm{Fe}^{2+}$ oxidation may play an important role in peroxygens activation. Keenan and Sedlak ${ }^{\mathbf{1 2}}$ found that accelerated $\mathrm{Fe}^{2+}$ oxidation in the presence of $\mathrm{Fe}$ surface significantly contributed to the enhanced $\mathrm{HCHO}$ yields from oxidation of $\mathrm{CH}_{3} \mathrm{OH}$ at $\mathrm{pH}>6.0$. Therefore, it is reasonably expected that surface-catalyzed $\mathrm{Fe}^{2+}$ reactions with peroxygens vary with the homogeneous reactions and deserves in-depth investigations in future.

\section{Conclusions}

In this work, commercially available $\mathrm{Fe}^{0}$ powder was used to activate three common peroxygens $\left(\mathrm{H}_{2} \mathrm{O}_{2}\right.$, PS and PMS) for the degradation of a model hazardous azo dye (i.e., AO7). Experimental data indicate $\mathrm{Fe}^{0}$ was an effective activator for peroxygens to treat azo dye at acidic $\mathrm{pH}$. The highest $\mathrm{AO} 7$ oxidation and mineralization were achieved in $\mathrm{Fe}^{0}$ activated $\mathrm{H}_{2} \mathrm{O}_{2}$ system at $\mathrm{pH}$ 2.5. However, the ability of $\mathrm{Fe}^{0}$ activated $\mathrm{H}_{2} \mathrm{O}_{2}$ system to oxidize $\mathrm{AO} 7$ was less than those of $\mathrm{Fe}^{0} / \mathrm{PS}$ and $\mathrm{Fe}^{0} / \mathrm{PMS}$ systems at $\mathrm{pH} \geqq 4.0$. Increasing iron dosage and peroxygens concentration favored a rapid degradation of $\mathrm{AO} 7$ in $\mathrm{Fe}^{0} / \mathrm{PS}$ and $\mathrm{Fe}^{0}$ / $\mathrm{H}_{2} \mathrm{O}_{2}$ systems. Addition of chloride could greatly inhibit dye removal in $\mathrm{Fe}^{0} / \mathrm{H}_{2} \mathrm{O}_{2}$ and $\mathrm{Fe}^{0} /$ PS systems, whereas dye degradation was accelerated in $\mathrm{Fe}^{0} / \mathrm{PMS}$ system. In contrast, no measurable mineralization of $\mathrm{AO} 7$ in $\mathrm{Fe}^{0} / \mathrm{PMS} / \mathrm{Cl}^{-}$system was observed. Some refractory chlorinated phenols, such as 2,3,6trichlorophenol, 2,4,5-trichlorophenol, 2,3,5-trichlorophenol, 2,4,6-trichlorophenol, 3,4-dichlorophenol, 2,5-dichlorophenol, 2,3-dichlorophenol and 2,4-dichlorophenol were identified by GC-MS. In conclusion, $\mathrm{Fe}^{0} / \mathrm{H}_{2} \mathrm{O}_{2}$ system is recommended to treat acidic and saline wastewater, while $\mathrm{Fe}^{0} / \mathrm{PS}$ and $\mathrm{Fe}^{0} / \mathrm{PMS}$ processes are more suitable for treatment of low salinity wastewater.

\section{Acknowledgements}

This work was supported by the National Natural Science Foundation of China (NSFC) (No. 21677031), National Key Research and Development Program of China (2016YFC0400501/ 2016YFC0400509), Shanghai Pujiang Program and DHU Distinguished Young Professor Program.

\section{References}

1 H. Zollinger, Colour Chemistry-Synthesis, 1987. 
2 Z. H. Wang, W. H. Ma, C. C. Chen and J. C. Zhao, J. Hazard. Mater., 2009, 168, 1246.

3 H. L. Lien and W. X. Zhang, Appl. Catal., B, 2007, 77, 110.

4 G. V. Lowry and K. W. Johnson, Environ. Sci. Technol., 2004, 38, 5208.

5 S. Choe, Y. Y. Chang, K. Y. Hwang and J. Khim, Chemosphere, 2000, 41, 1307.

6 J. Cao, L. P. Wei, Q. G. Huang, L. S. Wang and S. K. Han, Chemosphere, 1999, 38, 565.

7 G. Roy, P. D. Donato, T. Görner and O. Barres, Water Res., 2003, 37, 4954.

8 S. Nam and P. G. Tratnyek, Water Res., 2000, 34, 1837.

9 F. S. Freyria, B. Bonelli, R. Sethi, M. Armandi, E. Belluso and E. Garrone, J. Phys. Chem. C, 2011, 115, 24143.

10 Y. He, J. F. Gao, F. Q. Feng, C. Liu, Y. Z. Peng and S. Y. Wang, Chem. Eng. J., 2012, 179, 8.

11 Y. Yuan, H. Q. Li, B. Lai, P. Yang, M. Gou, Y. X. Zhou and G. Z. Sun, Ind. Eng. Chem. Res., 2014, 53, 2605.

12 C. R. Keenan and D. L. Sedlak, Environ. Sci. Technol., 2008, 42, 1262.

13 S. H. Chang, K. S. Wang, S. J. Chao, T. H. Peng and L. C. Huang, J. Hazard. Mater., 2009, 166, 1127.

14 O. X. Leupin and S. J. Hug, Water Res., 2005, 39, 1729.

15 C. E. Noradoun and I. F. Cheng, Environ. Sci. Technol., 2005, 39, 7158.

16 S. H. Joo, A. J. Feitz, D. L. Sedlak and T. D. Waite, Environ. Sci. Technol., 2005, 39, 1263.

17 C. J. Liao, T. L. Chung, W. L. Chen and S. L. Kuo, J. Mol. Catal. A: Chem., 2007, 265, 189.

18 M. A. Al-Shamsi, N. R. Thomson and S. P. Forsey, Chem. Eng. J., 2013, 232, 555.

19 J. Y. Zhao, Y. B. Zhang, X. Quan and S. Chen, Sep. Purif. Technol., 2010, 71, 302.

20 S. Y. Oh, S. G. Kang and P. C. Chiu, Sci. Total Environ., 2010, 408, 3464 .

21 C. J. Liang and M. C. Lai, Environ. Eng. Sci., 2008, 25, 1071.

22 Z. H. Wang, R. T. Bush, L. A. Sullivan and J. S. Liu, Environ. Sci. Technol., 2013, 47, 6486.

23 Z. H. Wang, R. T. Bush, L. A. Sullivan, C. C. Chen and J. S. Liu, Environ. Sci. Technol., 2014, 48, 3978.

24 I. Hussain, Y. Q. Zhang and S. B. Huang, RSC Adv., 2014, 4, 3502.

25 X. X. Jiang, Y. L. Wu, P. Wang, H. J. Li and W. B. Dong, Environ. Sci. Pollut. Res., 2013, 20, 4947.

26 S. Rodriguez, L. Vasquez, A. Romero and A. Santos, Ind. Eng. Chem. Res., 2014, 53, 12288.

27 Y. X. Wang, H. Q. Sun, X. G. Duan, H. M. Ang, M. O. Tadé and S. B. Wang, Appl. Catal., B, 2015, 172-173, 73.

28 H. Y. Shu, M. C. Chang and C. C. Chang, J. Hazard. Mater., 2009, 167, 1178.
29 J. A. Mielczarski, G. M. Atenas and E. Mielcazrski, Appl. Catal., B, 2005, 56, 289.

30 A. Rastogi, S. R. Al-Abed and D. D. Dionysiou, Appl. Catal., B, 2009, 85, 171.

31 J. Sharma, I. M. Mishra, D. D. Dionysiou and V. Kumar, Chem. Eng. J., 2015, 276, 193.

32 P. Maruthamuthu and P. Neta, J. Phys. Chem., 1977, 81, 937.

33 Washington and DC, Environmental Protection Agency, 1997.

34 S. N. Ramjaun, R. X. Yuan, Z. H. Wang and J. S. Liu, Electrochim. Acta, 2011, 58, 364.

35 R. X. Yuan, S. N. Ramjaun, Z. H. Wang and J. S. Liu, Chem. Eng. J., 2012, 192, 171.

36 R. X. Yuan, S. N. Ramjaun, Z. H. Wang and J. S. Liu, Chem. Eng. J., 2012, 209, 38.

37 C. L. Fang, D. X. Xiao, W. Q. Liu, X. Y. Lou, J. Zhou, Z. H. Wang and J. S. Liu, Chemosphere, 2016, 144, 2415.

38 J. Zhou, J. H. Xiao, D. X. Xiao, Y. G. Guo, C. L. Fang, X. Y. Lou, Z. H. Wang and J. S. Liu, Chemosphere, 2015, 134, 446.

39 R. X. Yuan, Z. H. Wang, Y. Hu, B. H. Wang and S. M. Gao, Chemosphere, 2014, 109, 106.

40 X. Y. Lou, Y. G. Guo, D. X. Xiao, Z. H. Wang and J. S. Liu, Environ. Sci. Pollut. Res., 2013, 20, 6317.

41 L. Xu, R. X. Yuan, Y. G. Guo, D. X. Xiao, Y. Cao, Z. H. Wang and J. S. Liu, Chem. Eng. J., 2013, 217, 169.

42 Z. H. Wang, R. X. Yuan, Y. G. Guo, L. Xu and J. S. Liu, J. Hazard. Mater., 2011, 190, 1083.

43 R. X. Yuan, S. N. Ramjaun, Z. H. Wang and J. S. Liu, J. Hazard. Mater., 2011, 196, 173.

44 W. Z. Yin, J. H. Wu, P. Li, X. D. Wang, N. W. Zhu, P. X. Wu and B. Yang, Chem. Eng. J., 2012, 184, 198.

45 Y. Hwang, D. Kim and H. S. Shin, Environ. Technol., 2015, 36, 1178.

46 T. X. Liu, X. M. Li and T. D. Waite, Environ. Sci. Technol., 2013, 47, 7350.

47 J. D. Laat and T. G. Le, Appl. Catal., B, 2006, 66, 137.

48 C. J. Liang, Z. Wang and N. Mohanty, Environ. Sci. Technol., 2006, 370, 271.

49 L. R. Bennedsen, J. Muff and E. G. Sogaard, Chemosphere, 2012, 86, 1092.

50 H. Li, J. Wan, Y. Ma, Y. Wang and Z. Guan, $R S C A d v ., 2015,5$, 99935.

51 S. N. Ramjaun, Z. H. Wang, R. X. Yuan and J. S. Liu, J. Environ. Chem. Eng., 2015, 3, 1648.

52 L. J. Matheson and P. G. Tratnyek, Environ. Sci. Technol., 1994, 28, 2045.

53 X. Sun, T. Kurokawa, M. Suzuki, M. Takagi and Y. Kawase, J. Environ. Sci. Health, Part A: Toxic/Hazard. Subst. Environ. Eng., 2015, 50, 1057. 